\title{
Body and Language: Enlivening Exhibitions of Colonial Women in Australian Museums
}

Toni Church

University of Notre Dame Australia

\begin{abstract}
The representation of women in galleries informs perceptions of women in society. Fieldwork conducted in Australian museums since 2017 has highlighted the discord between understandings of the historical role and autonomy of Australian women and the accurate embodiment of their stories in exhibition spaces. Museum exhibitions are imbued with qualitative cultural information and meaning led by curatorial intent, but also inflected with visitormade meaning. Subtle nuances of language and physicality in curatorial and exhibition design communicate messages, overt or subliminal, to audiences who carry pre-conceived cultural understandings about the world around them. This article addresses how curatorial intent and visitor interpretation produces understandings of Australian womanhood within museum exhibitions, and ways in which the methodology of displays can be adjusted to more accurately portray these women's autonomous voices and experiences.
\end{abstract}

'In this country, there are more statues of animals than there are of real Australian women', wrote Tracey Spicer in an editorial in The Sydney Morning Herald in September 2017. ${ }^{1}$ Spicer targeted the physical representation, including language, used to commemorate real (non-fictional, non-royal) women, who have been publicly cast as statues across Australia, and around the Western world. ${ }^{2}$ She further reflected that women are severely underrepresented, in their own right, in public memorialisation in Australia's

1 Tracey Spicer, 'Why Aren't More Women Immortalised in Stone?', Sydney Morning Herald, 29 September 2017, www.smh.com.au/lifestyle/tracey-spicer-why-arent-more-women-immortalisedin-stone-20170928-gyqm59.html.

2 Ibid. 
built landscape. She concluded that this 'marble ceiling', a phrase borrowed from an American study, sends a message that women's contribution to public life is not worthy of recognition. ${ }^{3}$

She built upon the work of Nilanjana Roy, whose editorial in the Financial Times a few months earlier called out the persistent 'statue gap' of the modern era-arguing that this visual silence:

goes beyond political correctness: what children and teenagers see of the world shapes their view of it, their sense of the place they should occupy. It's not enough to have women's images reflected only in billboards and advertisements - they must also be part of historical memory. ${ }^{4}$

The meaningful recognition of women's contributions to history in Australia has arguably not yet been fully (and accurately) translated into public memorialisation and, as an extension, in cultural heritage practice. A lack of accurate representation of women's contribution to Australian history informs broader public assumptions that this contribution is insignificant.

Reframing how women are represented within Australian cultural heritage by enlivening their experiences through language and physicality, can contribute to them being more accurately remembered in Australian historical memory. While cultural heritage encapsulates statues, memorials, built heritage, oral history, galleries and more, this paper will use industry practice in leading Australian museums and galleries and the methods they employ as examples of the representation of stories and experiences of women in public spaces. Once an exhibition subject is chosen, the methods employed by these museums to personify female characters fall into two main categories: language and physicality.

While the poetics of exhibition design produce meaning through the interrelation of elements within the display, it is the choices of language that most clearly articulate curatorial perspective and intent, and influence how a visitor perceives these chosen characters and stories on display. ${ }^{5}$ Museums also wield the physical in their storytelling. More specifically, the physical representation of bodies within galleries project subconscious cultural signposts to which visitors respond. It has long been established

3 Ibid.

4 Nilanjana Roy, 'Why Aren't There More Statues of Women?', Financial Times, 7 June 2017, www.ft.com/content/2f9137c6-49ff-11e7-a3f4-c742b9791d43.

5 Rhiannon Mason, 'Cultural Theory and Museum Studies', in A Companion to Museum Studies, ed. Sharon Macdonald (Chicester: Wiley, 2008), 20. 
that museum objects provide visitors with a 'touchstone for their life experiences', but even more subtle design features influence a visitor's perception of the subject and can reinforce societal values. ${ }^{6}$

This paper will address the embodiment of women's stories through mannequin design, pose and costume to understand the power that museums have in altering traditional forms of female characterisation. Such alterations can lift the character of real-life women out of stock standard mannequin bodies, and place their words, their self-reflection and their autonomy into the exhibition space. More specifically, it will look at methods of representing colonial Australian women in gallery spaces. Historically, this group were tied to their male counterpartsboth in life and appearance in historical memory-but following trends in academic feminist historiography that more fully embraced women's autonomy on the frontier, museums also brought Australian colonial women into their galleries.

In 2017, when Spicer penned her article on the public memorialisation of women in Australia, I was undertaking fieldwork in support of the beginnings of a $\mathrm{PhD}$ thesis broadly covering the representation of colonial women in museums across major cities in Australia, and how this practice might translate into my own creative work curating an exhibition highlighting the autonomy of European women who travelled to early Western Australia. The purpose of this fieldwork was to investigate how industry practice was reflecting well-worn and accepted feminist scholarship in the recognition of women in Australian history and translating these stories and practice into museology for the populace. Opportunities to access a broad range of museums are limited in Western Australia, so it was decided that fieldwork could most effectively be conducted in major cities in eastern Australia, where there are multiple galleries in a relatively small area. Therefore, fieldwork was localised to museums and galleries in Melbourne, Sydney and around the Hobart area in September 2017. State and local government institutions, as well as some community or privately funded museums were included in order to understand trends in the representation of women in galleries across the sector. ${ }^{8}$

6 Elizabeth Wood and Kiersten F Latham, The Objects of Experience: Transforming Visitor-Object Encounters in Museums (Walnut Creek: Routledge, 2016), 24.

7 These are, of course, European women - mostly middle-class educated British women—whose experiences of the frontier was vastly different to those of other classes, races or nationalities, let alone Aboriginal or Torres Strait Islander women who (for brevity) are not covered in this paper.

8 Both museums and art galleries were included in the fieldwork. 
While some sites and exhibitions were chosen due to their content being anticipated to relate to the research topic, in the first instance institutions were chosen mainly because of their practice. For example, while the Cascades Female Factory near Hobart seemed a natural choice for the project due to the institution's focus on the representation of women in a colonial context, valuable information about audience positioning and interactive design techniques was also found at the temporary exhibition 'The Pool' at The Ian Potter Centre, National Gallery of Victoria (NGV) Australia in Melbourne, which displayed an altered version of the Australian exhibition displayed at the 2016 Venice Architecture Biennale. ${ }^{9}$ Exhibition content was also considered, with preliminary research having identified some permanent and temporary exhibitions related to the experiences of women in Australia, and more specifically those in a colonial context. Case studies in this paper include Melbourne Museum, Allport Library and Museum in Hobart, and the Museum of Applied Arts and Sciences in Sydney. Melbourne Museum was selected as a case study due to their all-encompassing permanent exhibition content, from Bunjilaka Aboriginal Cultural Centre through to natural and broader social history displays. ${ }^{10} \mathrm{~A}$ section of the 'Evolution' gallery, which illustrated colonial scientific study, will be discussed as a case study later in this paper. Similarly, 'Bird Woman', a temporary exhibition at Allport Library and Museum within the State Library of Tasmania, was selected for similar themes of scientific work in colonial Australia, and explored the works of artist Elizabeth Gould in a contrasting fashion to Melbourne Museum's display. ${ }^{11}$ Lastly, the Museum of Applied Arts and Sciences (Powerhouse Museum) in Sydney was selected for their range of permanent social history exhibitions, as well as the 'Love Is ... Australian Wedding Fashion' temporary exhibition, which displayed some early colonial wedding dresses and provided consideration of the treatment and display of colonial female bodies within exhibition spaces. ${ }^{12}$

9 'Cascades Female Factory', Port Arthur Historic Site Management Authority, www.female factory.org.au; 'The Pool', The Ian Potter Centre, NGV Australia, 18 August 2017 - 18 February 2018, www.ngv.vic.gov.au/exhibition/the-pool/.

10 'Melbourne Museum', Museums Victoria, museumsvictoria.com.au/melbournemuseum/.

11 'Bird Woman', Allport Library and Museum of Fine Arts (State Library of Tasmania), 8 September 2017 - 27 January 2018.

12 'Love Is ... Australian Wedding Fashion', 13 May 2017 - 20 May 2018, Museum of Applied Arts and Sciences, maas.museum/event/love-is-australian-wedding-fashion/. 


\section{Historical and Theoretical Background}

Spicer's words felt pertinent to my fieldwork, particularly as gallery after gallery were scanned in the search for an autonomous female perspective, which was certainly there, but was overwhelmed with what I was beginning to recognise as a pervasive gender gap in both written and physical recognition within museums. Specifically, colonial women existed in the Australian history on display while men acted. ${ }^{13}$ This was reiterated by exhibition text that either largely sidelined their achievements, presented women solely within the context of their husbands or male guardians, or through the physical misrepresentation of colonial women's bodies on display. This exists in stark contrast to the well-established academic feminist historiography related to colonial women in Australia that has been developing since the 1970s. From the latter half of the twentieth century, historians such as Anne Summers, Miriam Dixon, Eve Pownall, Susanna de Vries and Deborah Oxley (among many others) wrote provocative and influential accounts of women's history in Australia that lay the foundation of feminist historiography in this country. ${ }^{14}$ Further, a focus on the diversity of histories about colonial (free, indentured or convict) women in Australia were popularised in academia from the 1990s and had a broad reach into the public sphere through education and popular discourse. ${ }^{15}$ The rise of

\footnotetext{
13 John Berger, Ways of Seeing (London: Penguin Books, 1972), 47.

14 See: Susanna De Vries, The Complete Book of Heroic Australian Women: Twenty-one Extraordinary Women whose Stories Changed History (Sydney: Harper Collins Publishers, 2010); Miriam Dixon, The Real Matilda: Woman and Identity in Australia 1788 to 1975 (Ringwood: Penguin Books, 1976); Deborah Oxley, Convict Maids: The Forced Migration of Women to Australia (Cambridge: Cambridge University Press, 1996); Eve Pownall, Australian Pioneer Women, 3rd ed. (Melbourne: Rigby Limited, 1964); Anne Summers, Damned Whores and God's Police, 2nd revised ed. (Melbourne: Penguin Books, 2002).

15 See Alison Alexander, The Ambitions of Jane Franklin: Victorian Lady Adventurer, 2nd ed. (Sydney: Allen \& Unwin, 2016); Rica Erickson, The Bride Ships: Experiences of Immigrants Arriving in Western Australia 1849-1889 (Perth: Hesperian Press, 1992); Jane Long, Jan Gothard and Helen Brash, eds., Forging Identities: Bodies, Gender and Feminist History (Perth: University of Western Australia Press, 1997); Raelene Frances and Bruce Scates, Women at Work in Australia: From Gold Rushes to World War II (Cambridge: Cambridge University Press, 1993); Raelene Frances, Selling Sex: A Hidden History of Prostitution (Sydney: UNSW Press, 2007); Raelene Frances, The Politics of Work: Gender and Labour in Victoria 1880-1939 (Cambridge: Cambridge University Press, 1993), doi.org/10.1086/ahr/101.1.228-a; Lucy Frost, No Place For A Nervous Lady: Voices from the Australian Bush (Melbourne: McPhee Gribble Publishers, 1984); Jan Gothard, Blue China: Single Female Migration to Colonial Australia (Melbourne: Melbourne University Press, 2001); Penelope Hetherington, Herstories - Our History: Bibliography of Western Australian Women's History (Perth: Edith Cowan University, 1998); Penelope Hetherington, Settlers, Servants \& Slaves: Aboriginal and European Children in Nineteenth-century Western Australia (Perth: University of Western Australia Press, 2002), doi. org/10.2307/27515946; Penelope Hetherington and Phillipa Maddern, eds., Sexuality and Gender in History: Selected Essays (Perth: Centre for Western Australian History, University of Western Australia, 1993); Susan Hunt, Spinifex and Hessian: Women in North-West Australia, 1860-1900 (Perth: University of Western Australia Press, 1986); Siân Rees, The Floating Brothel: The Extraordinary True Story of an 18thcentury Ship and its Cargo of Female Convicts, 2nd ed. (Sydney: Hodder Headline Australia, 2002), doi. org/10.2307/27516857; Patricia Crawford and Philippa Maddern, eds., Women as Australian Citizens: Underlying Histories (Melbourne: Melbourne University Press, 2001).
} 
feminist histories from the late twentieth century illuminated Australian women's experiences in the colonial archive-describing in their own words, in letters, diaries and personal communication, their lives on the Australian frontier, and highlighting their autonomy.

Since the 1970s, museums have undergone significant cultural change, not least in embracing the 'history from below' movement mirrored in the democratisation of social history in academia. ${ }^{16}$ Alison Bartlett and Margaret Henderson, Australian academics involved with the National Library of Australia's 2013 symposium 'Feminism and the Museum', argue that in line with this 'history from below' movement, feminism deserves 'a place in the museological production of social memory'. ${ }^{17}$ Feminist research in museums is a fledgling discipline, but significant research has addressed varied concerns about depictions of women in exhibitions, and their representation in narratives of cultural heritage. ${ }^{18}$ Amongst this research, there is a common focus on how museum materialities, as Arndís Bergsdóttir refers to them, as well as gendered power relations, conventionally place male figures at the centre of museum narratives. ${ }^{19}$ British museum consultant and academic Gaby Porter argues that these museum materialities, including text, objects and design, which reduce or omit women from exhibition spaces not only occur at a curatorial level, but within museum processes and deeper knowledge production-in turn affecting how objects are categorised, interpreted and employed within exhibition spaces and museum collections. ${ }^{20}$ Further, Porter has argued,

16 Alison Bartlett and Margaret Henderson, 'Feminism and the Museum in Australia: An Introduction', Journal of Australian Studies, 40, no. 2 (2016): 130-2.

17 Ibid., 132.

18 See Bartlett and Henderson, 'Feminism and the Museum in Australia', 129-39; Arndís Bergsdóttir, 'Museums and Feminist Matters: Considerations of a Feminist Museology', NORA - Nordic Journal of Feminist and Gender Research, 24, no. 2 (2016): 126-39, doi.org/10.1080/08038740.2016.1182945; Katy Deepwell, 'Feminist Curatorial Strategies and Practices since the 1970s', in New Museum Theory and Practice, ed. Janet Marstine (Chichester: Wiley-Blackwell, 2008), doi.org/10.1002/9780470776230. ch2; Amy K Levin, ed., Gender, Sexuality and Museums: A Routledge Reader (New York: Routledge, 2010); Jane R Glaser and Artemis A Zenetou, eds., Gender Perspectives: Essays on Women in Museums (Washington DC: Smithsonian Institution Press, 1994); Viv Golding, 'Museums, Poetics and Affect', Feminist Review, 104, no. 1 (2013): 80-99, doi.org/10.1057/fr.2013.2; Hilde Hein, 'Looking at Museums from a Feminist Perspective', in Gender, Sexuality and Museums: A Routledge Reader, ed. Amy K Levin (Oxon, UK: Routledge, 2010), 53-64, doi.org/10.4324/9780203847770; Hilde Stern Hein, 'Redressing the Museum in Feminist Theory', Museum Management and Curatorship, 22, no. 1 (2007): 31-4, doi.org/10.1080/09647770701264846; Gaby Porter, 'Seeing through Solidity: A Feminist Perspective on Museums', The Sociological Review, 43, no. S1 (1995): 105-26, doi.org/10.1111/j.1467954x.1995.tb03427.x.

19 Bergsdóttir, 'Museums and Feminist Matters', 128.

20 Porter, 'Seeing through Solidity', 105-26. 
even curators who have addressed this gender imbalance have themselves largely reinforced cultural assumptions of gender. ${ }^{21}$ Their exhibitions tend to reduce women to traditionally passive or shallow roles, idealising women who fitted the mould, and leaving behind those deemed to be more 'difficult'. Alternatively, they have granted these 'difficult' women a disproportional focus inside exhibition narratives - such as those outstanding, royal or criminal women of the most popular displays. ${ }^{22}$ This is accomplished through both language, with crafted exhibition text, and physical design; the deliberate selection of objects, their placement, and representation of figures in galleries, which also contribute to visitor-made meaning within the gallery.

The physical representation used by curators and designers to characterise historical figures in museums and galleries tells their audience almost as much as the written content in text panels and object labels. Exhibition elements are imbued with varying social meaning and qualitative cultural information, while the gaps are filled with text, to generate and reproduce collective knowledge within the viewer. ${ }^{23}$ Museum objects are largely 'mute and unreadable' to visitors without some form of curatorial explanation and narrative involvement. ${ }^{24}$ The cohesive positioning and location of objects, and collective exhibitions within the walls of the museum, communicate much more than is written on text panels, or explained through object labels, and has a profound social impact through its display. Therefore, it is unavoidable that there are intrinsic social assumptions and beliefs, influenced by culture, within gallery representations. ${ }^{25}$ Museum practices reflect the society in which they are placed. In a Western context, this has resulted in colonial, imperialist and masculinist interpretations being privileged. ${ }^{26}$ Numerous academics across disciplines have argued that in Western patriarchal societies, 'men have controlled who looks

\footnotetext{
21 Ibid., 108-9.

22 Ibid.

23 Hilde Hein, quoted in: Michelle Henning, Museums, Media and Cultural Theory (Maidenhead, England: Open University Press, 2006), 6-7; Adrian B Evans, 'Enlivening the Archive: Glimpsing Embodied Consumption Practices in Probate Inventories of Household Possessions', Historical Geography, 36 (2008): 44; Bartlett and Henderson, 'Feminism and the Museum in Australia', 131; Susan A Crane, 'The Conundrum of Ephemerality: Time, Memory, and Museums', in A Companion to Museum Studies, ed. Sharon Macdonald (Chichester: Wiley, 2008), 99.

24 Katherine Louise Gregory, 'The Artist and the Museum: Contested Histories and Expanded Narrative in Australian Art Museology, 1975-2002' (PhD, University of Melbourne, 2004-10), 267.

25 Usha Bande, 'Introduction', in Boundaries of the Self: Gender, Culture and Spaces, ed. Debalina Bannerjee (Newcastle-upon-Tyne: Cambridge Scholars Publishing, 2014), 4.

26 Hein, 'Looking at Museums from a Feminist Perspective', 53-64.
} 
at whom'. ${ }^{27}$ Due to this overarching influence, it's not only men who do the looking, but society as a whole has been provided with what Beth Eck has labelled 'readily available cultural scripts' for interpreting and responding to femininity on display. ${ }^{28}$ Therefore, it is not just the curatorial and exhibition design that influences the visitor, but also their own social and cultural conditioning that guides their interpretation of the museum narrative. Further, it must be acknowledged that meaning is made as much by curatorial intent and carefully considered design, as by the social values and beliefs of the audience. This means that in both museum collections, and in the public exhibitions that utilise these objects, it is the museum staff who influence the narrative that depicts the wives, sisters and, daughters (and mistresses) of great men as footnotes to masculine achievement. In an Australian context, these women have become mere additions to the narrative of progress that marched across this declared-empty continent.

\section{A Study of Language: Exhibiting Elizabeth Gould}

The striking difference in curatorial language used to illuminate the life and work of Elizabeth Gould, a colonial-era scientific artist, highlights the power of words within an exhibition to both reflect and influence visitormade meaning within the museum, and wider social understandings of historical women in Australia. Gould featured in both a permanent natural history display at Melbourne Museum, and a temporary exhibition titled 'Bird Woman' at Allport Library and Museum of Fine Arts (State Library of Tasmania) in Hobart, on display from September 2017. ${ }^{29}$ In both galleries, Gould was presented as the wife of John Gould, whose publication Birds of Australia was a definitive nineteenth-century text on native ornithology in this country. Traditionally, Gould's work was overshadowed by her husband who assumed credit for her artistic work after her death, effectively

27 See: Rosalind Coward, Female Desires: How They Are Sought, Bought and Packaged (New York: Grove Weidenfeld, 1985); Melody D Davis, The Male Nude in Contemporary Photography (Philadelphia: Temple University 1991); Berger, Ways of Seeing.

28 Beth A Eck, 'Men Are Much Harder: Gendered Viewing of Nude Images', Gender and Society, 17, no. 5 (2003): 691-3.

29 'Evolution Gallery', Melbourne Museum; Jess Walters, 'Bird Woman: Elizabeth Gould and the Birds of Australia', Tasmanian Archive and Heritage Blog, 7 November 2017, archivesandheritageblog. libraries.tas.gov.au/bird-woman-elizabeth-gould-and-the-birds-of-australia/. 
removing her contribution from historical memory. ${ }^{30}$ The permanent, and arguably out-dated, display at Melbourne Museum reinforces this narrative by giving little recognition to Gould's accomplishments as an artist, instead emphasising her domestic work as a wife and mother. ${ }^{31}$ Alternatively, Allport Library and Museum characterises Gould as an artist in her own right, who developed her craft through travel with her husband and honed her scientific observation while in Tasmania in order to produce the acclaimed imagery in her husband's publication. ${ }^{32}$ The difference in characterisation in these exhibitions is significant because it highlights the impact of interpretation of a single subject through language, and reflects the changes in museum practice towards greater inclusivity of feminist historiography and acceptance in wider historical memory in Australia.

Choices in exhibition language have relegated Elizabeth Gould, a prolifically talented scientific artist in her own right, to a secondary figure alongside her husband John Gould, who is glorified in the natural history display at Melbourne Museum. ${ }^{33}$ Although an accomplished artist who produced a large number of lithographs and prints of Australian birds for publication in her husband's book, Birds of Australia, Gould is not the feature of the display. ${ }^{34}$ The language of the text panel featuring Gould highlights (in bold text) her perceived key achievement: 'Elizabeth Coxen married John Gould in 1829'. ${ }^{35}$ On the other hand, John Gould's achievements are lauded; his illustrations and scientific plates are cited as 'magnificent works of art and important scientific documents'. ${ }^{36}$ The objects chosen to accompany these pieces of text include illustrations from the large-scale scientific publication, as well as tickets to the Gould's exhibition of hummingbirds in London. ${ }^{37}$

The juxtaposition of language clearly positions John Gould as the hero, emphasising his production of Birds of Australia as more significant than Elizabeth's Gould's domestic work. The language used in text panels about

\footnotetext{
30 Walters, 'Bird Woman'.

31 'Evolution Gallery', Melbourne Museum.

32 'Bird Woman', Allport Library and Museum of Fine Arts.

33 'Evolution Gallery', Melbourne Museum.

34 'Gould, Elizabeth (1804-1841)', Australian National Herbarium, last updated 11 September 2013, www.anbg.gov.au/biography/gould-elizabeth.html; AH Chisholm, 'Gould, Elizabeth (1804-1841)', Australian Dictionary of Biography, published first in hardcopy 1966, adb.anu.edu.au/biography/ gould-elizabeth-2112/text2665.

35 'Evolution Gallery', Melbourne Museum.

36 Ibid.

37 Ibid.
} 
John Gould tie him more significantly to the objects on display, while the lesser amount of text about Elizabeth Gould notes her (secondarily) as a contributing artist. ${ }^{38}$ No other mention of Elizabeth Gould was found in the gallery. A single coloured portrait was the only other physical evidence of her existence. ${ }^{39}$ Through this curatorial narrative, Elizabeth Gould's contribution is minimised-sidelined with domesticity as her focus, and overpowered by the significance placed on her husband's contributions outside of the home and their marriage. The selection of curatorial design to emphasise the text about her marriage, rather than the large number of scientific illustrations she produced, aligns with the gendered expectations of nineteenth-century colonial women. This traditional approach to women's representation in Australian history means that, to a visitor of this exhibition, Elizabeth Gould's existence and her historical significance is defined by her relationship to her husband. Her autonomy is reduced by this narrative of dependency upon him for recognition, and reinforces the traditional gender bias in Australian public memory.

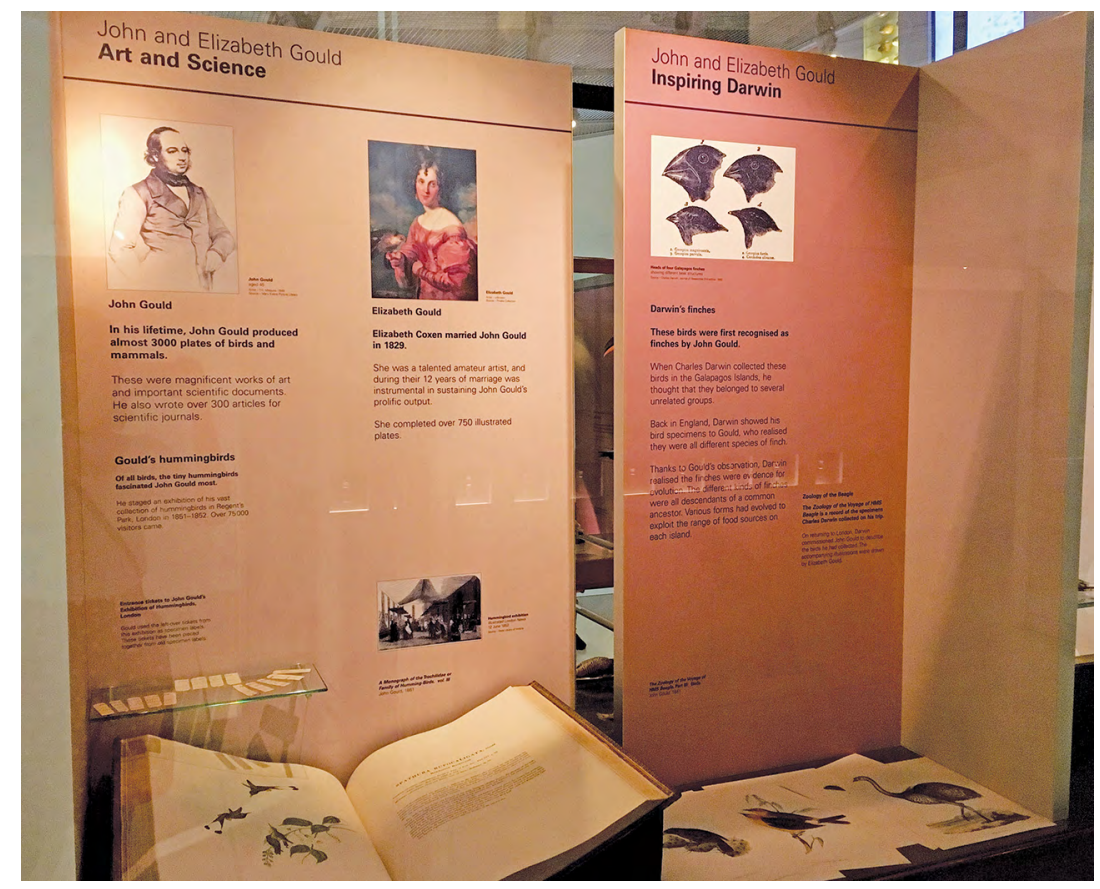

Figure 1: Melbourne Museum, 2017.

Source: Toni Church. 
In 2017, Allport Library and Museum of Fine Arts in Hobart provided an alternative interpretation of the role of Elizabeth Gould. The 'Bird Woman' exhibition presented the Gould's artistic works and implements, with very similar objects to those on display in Melbourne Museum, but with a narrative weighed heavily in favour of Elizabeth Gould. ${ }^{40}$ The introductory text panel at the entrance of the gallery acknowledged that her 'role in the production of Gould's books has been understated and overlooked'. ${ }^{41}$ This explicit acknowledgement of the historical silence surrounding Elizabeth Gould's contribution frames the exhibition as both an exercise in truth-telling, and brings this history into line with now-accepted historical understandings of the contribution of women in the colonial era. The panel went on to articulate the main theme of the exhibition by stating that 'Elizabeth Gould the Birdwoman was the equal partner in life and work to John Gould the Birdman', a stark departure from the traditional trope. ${ }^{42}$ Further curatorial interpretation gave reasons for Elizabeth Gould's limited notoriety; text panels summarised how the gendered expectations of nineteenth-century womanhood had hidden Elizabeth Gould's 'artistic endeavours ... within the family home and business', while also noting that her early death at 37 further obscured her role, and allowed for her husband to assume credit for her works in his publications. ${ }^{43}$ The conscious framing of Elizabeth Gould as a significant contributor to her husband's publications through careful selection of language provides a powerful statement on the role of women in colonialera scientific productions in Australia. Allport Library and Museum directly address the gender imbalance in this historical memory, with their curators using direct and unambiguous language to frame Elizabeth Gould as a significant scientific artist in her own right. In doing so, they have strongly contributed to redressing the historical imbalance in the Australian collective memory of colonial women.

There is a marked difference in the nature of both the curation and display of the two exhibitions in Melbourne and Hobart. ${ }^{44}$ In the case of Elizabeth Gould, it is not the objects but the textual interpretation that simultaneously sidelines and highlights her contribution. The objects are

\footnotetext{
40 'Bird Woman', Allport Library and Museum of Fine Arts.

41 Ibid.

42 Ibid.

43 Ibid.

44 Admittedly, the Melbourne Museum display has not aged well, and represents the challenges of museums to maintain their currency amidst a changing social and cultural landscape. Their updated gallery spaces, within the same building, are recognised as leading examples of industry excellence.
} 
the same. The history is the same. However, the methods and manner of interpretation provide the audience with vastly different meanings. This gendered bias at once reinforces preconceived notions of women's role in scientific advancement through the positioning of Elizabeth Gould's narrative as secondary to her husband. Further, it cements any of her achievements as wholly reliant upon him. Other Australian exhibitions have addressed similar themes, such as Sydney Living Museums' 2016 exhibition 'The Artist \& the Botanical Collector' about the publishing partnership between Gertrude Lovegrove and William Bäuerlen. Framed as a coming together of equal minds, Lovegrove the artist and Bäuerlen the collector pursued the ambitious (but ultimately unsuccessful) multipart publication of The Wild Flowers of New South Wales. ${ }^{45}$ The Australian Museum's current touring exhibition 'Transformations: Art of the Scott Sisters' seeks to further highlight the contribution of women in the production of scientific illustrations in colonial Australia. ${ }^{46}$ Placing the works of Harriet and Helena Scott as the subject of this exhibition, the accompanying text characterises them as 'two of 19th-century Australia's most prominent natural history illustrators ${ }^{4}{ }^{47}$ By pointedly not qualifying their gender in this statement, the curators give weight to the Scotts' contribution to the scientific world as equal and deserving of attention based on their skills, not the extraordinary nature of their behaviour given the gendered expectations of their time. Somewhat subtle but powerful adjustments in language used in exhibitions and publicity materials affects visitor's perceptions of curatorial subjects in museums. By reflecting on choices of language, museums are contributing to popular discourse and understandings of Australian historical memory; and, in the case of Elizabeth Gould, are both continuing the trend of feminist historiography in academia, and directly influencing the increasing recognition of the roles of women in colonial Australia.

45 'The Artist \& The Botanical Collector: The Lost Works of Lovegrove \& Bäuerlen', Museum of Sydney (Sydney Living Museums), 13 August 2016 - 20 November 2016, sydneylivingmuseums. com.au/exhibitions/artist-botanical-collector.

46 'Touring exhibition: Transformation: Art of the Scott Sisters', Australian Museum, 2020, australianmuseum.net.au/get-involved/services/touring-exhibits/transformations-art-of-the-scottsisters-exhibition/.

47 Ibid. 


\section{A Study of the Physical: Mannequin Bodies}

Clothing presents vast potential for interpretation, particularly in exhibitions focusing on the individual stories and historical imprint of women, as it enables visitors 'to make tangible, meaningful mental links with the past'. ${ }^{48}$ The embodied nature of costume collections enables a more personal connection with the audience. ${ }^{49}$ Displaying costume collections in a manner that is authentic to the historical figures being represented is a challenge. Ingrid Mida, Fashion Research Collection Coordinator at Ryerson University, has investigated the challenge posed to costume curators whose collections and exhibitions must communicate that a dress artefact was once worn by a living person and therefore embodies a complex interplay of cultural beliefs, identity, memory, and body imprints. ${ }^{50}$ The interpretive designs for standard objects and artefacts, such as display cases or plinths, do not allow for the accurate embodiment of clothing items in order to flesh out the person who once wore the costume, and produce an emotional affect with the audience. In lieu of the live bodies who wore the clothing, mannequins have become the industry standard design feature that 'bring to life' costume collections, using a constructed bodily form to make an inextricably human connection between visitor and object.

When mannequins take a female form within a museum gallery, the bodies on display are perceived by visitors with the same cultural consciousness as women in their society. The mannequin form itself, when not on display, does not purvey particular meaning to an absent audience. However, when that feminised figure is curated, accompanied by a design aesthetic, recognisable social indicators such as pose and accessorised in such a way as to produce meaning, the impact of these social and cultural marks becomes clearly evident. Put simply, when women are displayed within the walls of a gallery, they become an object. Whether represented by painting, material culture or modelled figure mannequins, these women are imbued with cultural significance and interpreted by cultural values. ${ }^{51}$

48 Julia Petrov, 'Cross-Purposes: Museum Display and Material Culture', CrossCurrents, 62, no. 2 (2012): 223.

49 Laura Neilson, 'How Museums and Cultural Institutions Have Shaped the History of Body Diversity,' Fashionista, 6 December 2017, fashionista.com/2017/12/mannequins-fashion-museumfit-body-exhibit.

50 Ingrid Mida, 'Animating the Body in Museum Exhibitions of Fashion and Dress', The Journal of the Costume Society of America, 41, no. 1 (2015): 38, doi.org/10.1179/0361211215z.00000000038.

51 Laura Mulvey, 'Dossier: Visual Pleasure at 40', Screen, 56, no. 4 (2015): 481-2; Laura Mulvey, 'Visual Pleasure and Narative Cinema', Screen, 16, no. 3 (1975): 6-18; Berger, Ways of Seeing. 
Amy Levin, Professor of Museum Studies at Northern Illinois University, has commented that 'regardless of the type of museum, its objects become subjects of gaze', with museums taking their place as a 'cultural apparatus' instructing visitors in approved culture and behaviours-including how to view female bodies. ${ }^{52}$ Feminine mannequins are laden with these cultural signposts, designed and posed as idealised female forms.

Such posing and perfecting of the female form is in stark contrast to a mannequin's purpose to display costume collections worn by real women, many of whom did not perform to social or cultural ideals, and produces a clash between the curatorial intent in displaying a costume object, on a socially ill-fitting mannequin form, which can result in an unintended perception of the curatorial subject by visitors. Visitors view the costume object through a lens of their own cultural, social and personal experiences, which means their perception of the curatorial subject is heavily influenced by the physical form on which it is displayed. As Joanne Entwistle highlighted, 'our experience of the body [within a gallery setting] is not as inert object but as the envelope of our being, the site for our articulation of self', for which curatorial and exhibition design staff are not immune. ${ }^{53}$ The distinct relationship between body and identity, and identity and dress, must be understood and then applied with care by those in museums who hold the power to influence the meaning-making of an exhibition. Understanding and working with this cultural and social interrelationship of feminised bodies in gallery spaces and visitor perception, is crucial when curating accurate representations of real women in museum exhibitions.

The contradiction between design and historical accuracy was observed through the exhibition design choices that posed colonial women as demure, shy, downward-facing mannequins in the Museum of Applied Arts and Sciences' (Powerhouse Museum, Sydney) 'Love Is ... Australian Wedding Fashion' exhibition in 2017.54 In this exhibition, colonial wedding dresses were displayed on fine-figured, almost child-like, mannequin dress forms with stylised hair and gentle features, standing with arms softly placed in passive positions. ${ }^{55}$ The mannequins had clearly

52 Amy K Levin, 'Introduction', in Gender, Sexuality and Museums: A Routledge Reader, ed. Amy K. Levin (Oxon, UK: Routledge, 2010), 5, doi.org/10.4324/9780203847770.

53 Joanne Entwistle, 'Fashion and the Fleshy Body: Dress as Embodied Practice', Fashion Theory, 4, no. 3 (2000): 335, doi.org/10.2752/136270400778995471.

54 'Love Is ... Australian Wedding Fashion'.

55 Ibid. 
been designed and positioned to adopt a stereotypical female personality of the nineteenth century. Small and diminutive in both physicality and behaviour, they projected a gentle demeanour, not taking up a lot of space with their bodies, and certainly not behaving as assertive figures. The mannequin's pose added another layer of character and personality to both the costume and the historical figure the curator represented in the exhibition. Pose is an important aspect of telling exhibition stories and creating meaning by mirroring human behaviour, and further engaging visitors through the embodiment of costume collections. ${ }^{56}$ However, the poses used to display these colonial wedding dresses did not fully communicate the complexities of the historical figures. Rather, they reinforced the stereotypical, sociocultural assumptions about nineteenthcentury colonial women in Australia, strengthening a narrative that is both inaccurate and damaging to the equal recognition of women's contributions in Australian collective memory.

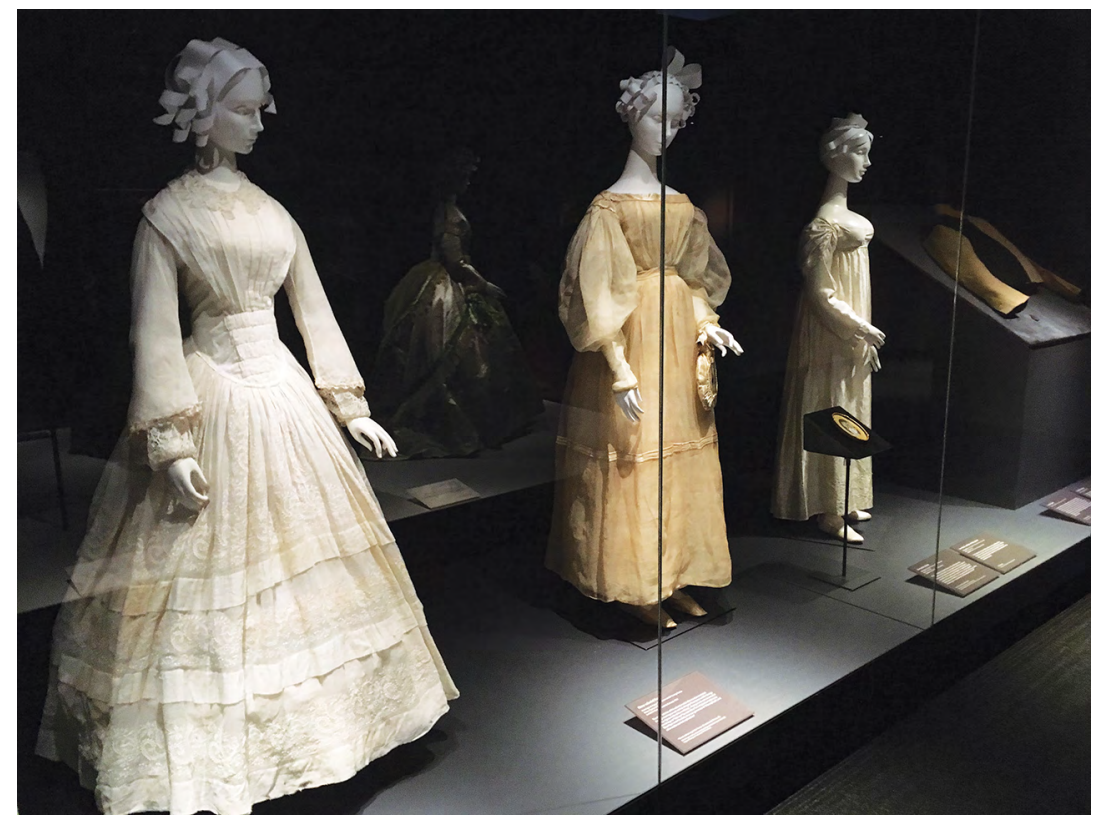

Figure 2: 'Love Is ... Australian Wedding Fashion', Museum of Applied Arts and Sciences, 2017.

Source: Toni Church.

56 Shelly Uhlir, 'Articulated Solutions for Mannequins in the Circle of Dance Exhibition at National Museum of Ths American Indian - New York', Journal of the American Institute for Conservation, 56, no. 1 (2017): 53, doi.org/10.1080/01971360.2016.1269552. 


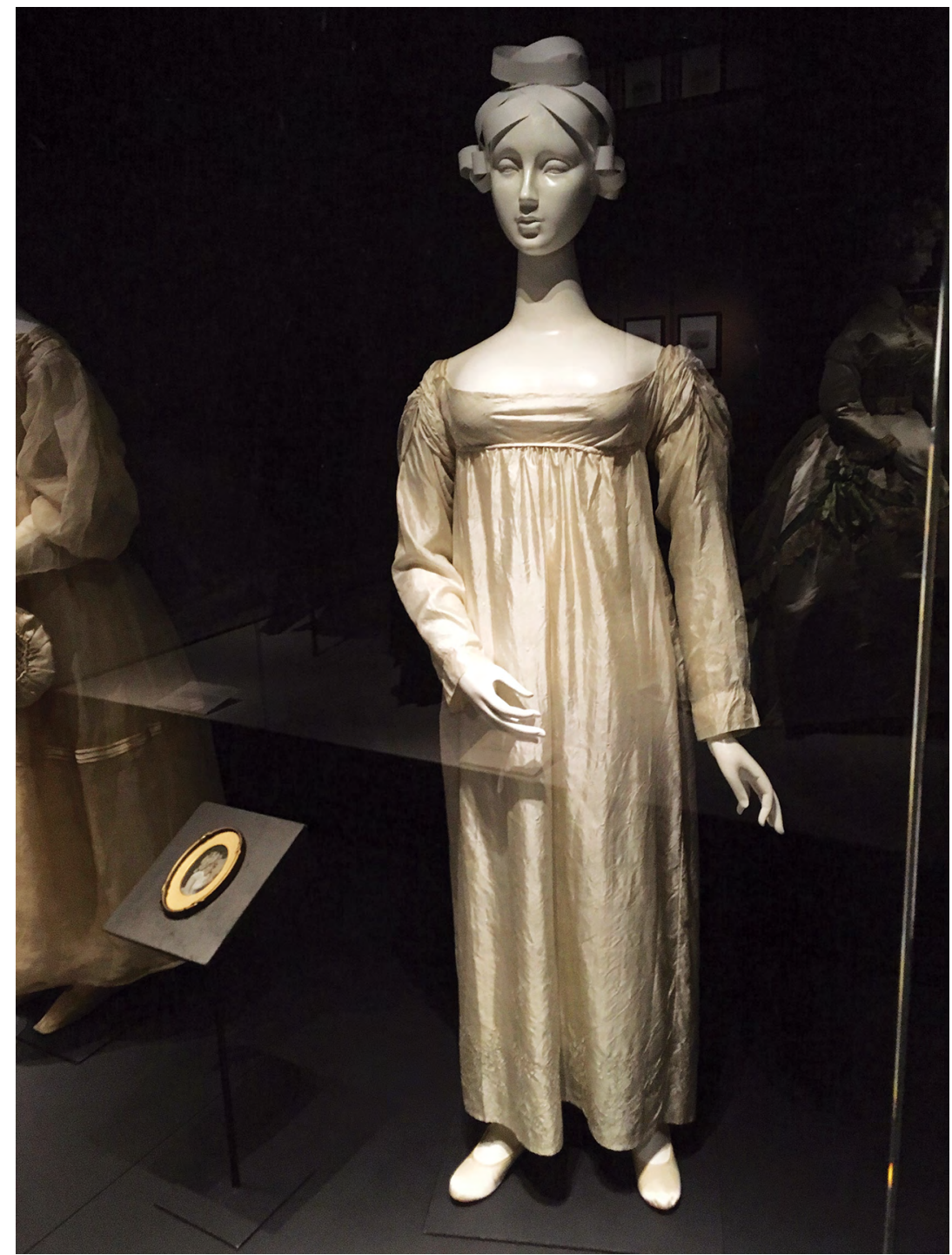

Figure 3: Australia's oldest surviving wedding dress, 'Love Is ... Australian Wedding Fashion', Museum of Applied Arts and Sciences, 2017.

Source: Toni Church.

There were sparse details included in the exhibition text about the women who wore these dresses, but further research indicated that these were vibrant, adventurous and generous colonial women whose personalities are not accurately portrayed by the posed figures hosting their dresses. Believed to be Australia's oldest surviving wedding dress, the pictured 
popular neoclassical style of gown is provenanced to Ann Marsden who married Reverend Thomas Hassall in Parramatta in 1822, but its display does not convey the courageous story of the generations of women who wore this dress. ${ }^{57}$ At a glance, the visitor may recognise the age of the gown, but will also perceive the type of woman who wore this dress. From the mannequin's soft and open hand gestures, delicately moulded facial features and crafted 'hair', the gentle persona (and European race) being conveyed by the mannequin design is clear. While this gentle personality may befit the original owners of this dress, the passivity of the mannequin's presence and pose in this display belies the difficulties endured by its wearers in their life on the colonial frontier. The absence of these colonial women's active and autonomous contributions to the processes of colonisation in this space perpetuates popular misunderstandings of women's experiences of the frontier, and the significant role they had in the settlement of Australia.

The dress was originally worn by Ann Marsden's mother Elizabeth Marsden (née Fristan) in her marriage to Samuel Marsden in April $1793 .{ }^{58}$ It appears that Elizabeth Marsden brought her wedding dress with her later that year when she travelled from England to Sydney with her husband-a priest destined for the new colony at Parramatta — giving birth to her first child, Ann, on the voyage, during a wild storm off the coast of Tasmania. ${ }^{59}$ While her husband attempted farming, despite his inexperience, as well as the evangelising of convicts and Aboriginal people, Elizabeth Marsden raised five daughters and a son in challenging environmental and social circumstances. Her husband's missionary work in Norfolk Island and New Zealand (over seven voyages) took him away from the family, leaving her isolated in the raising of the family. His reputation as a harsh colonial magistrate and his staunch opposition to the colonial government surely made for an uncomfortable social predicament, at best, for his wife. ${ }^{60}$ The style and typical pose of mannequin used to display the dress does little to embody both Elizabeth's, and later her daughter Ann's, intrepid

57 Lydia Edwards, How to Read a Dress: A Guide to Changing Fashion from the 16th to the 20th Century (London: Bloomsbury Academic, 2017), 68; 'Love Is ... Australian Wedding Fashion'.

58 'Love Is ... Australian Wedding Fashion'; Glynis Jones, 'Love is ... Highlights from the MAAS Wedding Dress Collection', Museum of Applied Arts \& Sciences, 13 February 2018, maas. museum/inside-the-collection/2018/02/13/love-is-highlights-from-the-maas-wedding-dresscollection/; AT Yarwood, 'Marsden, Samuel (1765-1838)', Australian Dictionary of Biography, adb. anu.edu.au/biography/marsden-samuel-2433.

59 AT Yarwood, 'Marsden, Samuel (1765-1838)'.

60 Ibid. 
bravery or personify their experiences on the colonial frontier. Overall, the uniformity of the demure mannequin design promotes a homogenous colonial experience for women and does not embody the complexities of personality or experiences of the original wearers of these garments.

\section{Curating Enlivened and Embodied Exhibitions}

The challenge for cultural heritage professionals, then, is how to accurately represent the former owner's full lived experience through the display of their collection. Challenging established social and cultural expectations, just as many of these colonial women did, is a key step in order to more fully embody their stories with action, autonomy and a more accurate representation of their lives on the frontier. What is remembered is important, but it is also the way history is remembered. How women are represented is just as important as their inclusion in the collective narrative. By embracing pluralism beyond merely tokenistic representations of women within exhibition narratives and curatorial selection, but also redressing the engrained notions of subjectivity within museum's processes and roles, museums have the potential to shift the perspectives of not just their content, but the perspectives and understandings of its audiences. ${ }^{61}$ There has been, and continues to be, a distinct shift in the way colonial narratives are told in this country. As we transition into a postcolonial society (with much work to come), the narrative of the frontier is becoming more inclusive-as it always was, but not always as it has been collectively remembered. By recognising that museums have traditionally been characterised by patriarchal barriers and controls, museum professionals have played a key role in initiating a transformation of this characterisation; initiating discussions of gender and inequality in the museum by exhibiting richer and more challenging histories. ${ }^{62}$ However, this transformation is still incomplete.

61 Bergsdóttir, 'Museums and Feminist Matters', 128; Hilde Stern Hein, 'Redressing the Museum in Feminist Theory', Museum Management and Curatorship, 22, no. 1 (2007): 31-4, doi. org/10.1080/09647770701264846.

62 Golding, 'Museums, Poetics and Affect', 81; Gaynor Kavanagh, Museum Provision and Professionalism (London: Routledge, 1994); Bergsdóttir, 'Museums and Feminist Matters', 129. 
Certainly, a shift in visitor perception led by curatorial and design influences is key. Providing audiences with more inclusive narratives through language and recognising the active role women played in processes of colonisation has been achieved in galleries such as Allport Library and Museum by repositioning female-driven narratives to the forefront of exhibition planning. ${ }^{63}$ This narrative shift aligns more fully with the lived experience of colonial women on the frontier, but also mirrors the evolution of feminist historical scholarship on these topics. From fieldwork conducted in exhibitions about women in Australian museums since 2017, it became clear that in order to more fully articulate colonial women's contributions to Australian historical memory, their language needs to be enlivened and physicality more accurately embodied. An appreciation of audience, and the sensory visitor experience is key to targeting all aspects of storytelling available in museums-particularly in communicating complex, often challenging, narratives. Some suggested methods of the reinterpretation of colonial women in Australian museums include the re-evaluation of language used to both describe and represent these women. Reconsidering traditional representations of the domestic as less valuable to contributions of public life, for example, can shift a masculine-focused narrative to one that considers the value of women's work on the frontier. Placing greater emphasis on the contribution of valuable domestic work, as well as highlighting the adaption of skills many women brought to the colonial experience can shift perceptions of women's contribution on the frontier. Similarly, reinterpreting objects previously regarded as masculine by applying revised language to encompass a more gender-diverse exhibition narrative is an effective (and budget-friendly) adjustment for museums-reinventing their collection through interpretation.

Imaginative designs and, arguably, creative budgeting are needed to transform the representation of female forms in museums and galleries. While it may take more effort, and a greater budget, to customise mannequin stock in order to more fully, and accurately, embody curatorial subjects, it is not always necessary in order to balance female representations 
in exhibitions. ${ }^{64}$ The inclusion of complementary interpretive materials can do this work to enliven the character of real-life women out of stock standard mannequin bodies, and place their words, their self-reflection, and their autonomy into the exhibition space. For example, where a masculine uniform immediately represents power and its enforcement, women's costume collections are rarely read in such a way. However, readjusting a colonial exhibition through the inclusion of a woman's costume piece, together with a reinterpretation of their role in 'civilising' the frontier through publishing their written work, representations of colonial power dynamics through art or broader audio-visual media, can more fully embody the original costume object and enliven the experience of this colonial woman to befit the curatorial subject. Museums should deliver these women's voices directly to the audience. This will enable those women to share with visitors their reflections, not only of their experiences of colonial life, but also the weight of their clothing, the heat of European layers under the Australian sun, and the blisters of uncomfortable footwear in sandy soil. The daily realities of womanhood in the environment of 'the other' cannot be communicated through the plastic bodies of a stagnant mannequin. These subtle shifts, from pose to curatorial focus, will enliven women, and their bodies, in our museums and galleries and, importantly, place their autonomy back into the colonial narrative and public memory. Only by more fully representing the diversity of our shared collective memory can we encourage widespread acceptance of a more diverse and inclusive collective identity.

64 A recent example of custom-made mannequins was in the Arts Centre Melbourne touring exhibition 'Kylie on Stage' (on display at the Western Australian Maritime Museum, 16 February - 9 June 2019). Displaying mannequins based on Kylie Minogue's body, to fit her performance costumes from the 1980s to 2015, they were posed as performers on stage, befitting the concert tour curatorial subject and adding to the enlivening of the costumes on display. 
This text is taken from Lilith: A Feminist History Journal: Number 26, published 2020 by ANU Press, The Australian National University,

Canberra, Australia.

doi.org/10.22459/LFHJ.26.02 